\title{
Serum ferritin, cardiovascular risk factors and ischaemic heart diseases: a prospective analysis in the SU.VI.MAX (SUpplementation en Vltamines et Minéraux AntioXydants) cohort
}

\author{
Pilar Galan ${ }^{1}$ * , Nathalie Noisette ${ }^{1}$, Carla Estaquio ${ }^{1}$, Sebastien Czernichow ${ }^{1}$, \\ Louise Mennen ${ }^{1}$, Jean-Charles Renversez ${ }^{2}$, Serge Briançon ${ }^{3}$, Alain Favier $^{2,4}$ and \\ Serge Hercberg ${ }^{1,5}$ \\ 'U557 INSERM (UMR INSERM/INRA/CNAM), Centre de Recherche en Nutrition, lle de France, Paris 13, Bobigny, \\ France: ${ }^{2}$ Département de Biologie Intégrée, CHU de Grenoble, France: ${ }^{3}$ Ecole de Santé Publique, Epidémiologie \\ clinique, Faculté de Médecine, CHU Nancy EA 3444, France: ${ }^{4}$ Laboratoire Lésions des Acides Nucléques, UMR \\ CNRS-CEA-UJF 5046, Grenoble, France: ${ }^{5}$ Unité de Surveillance et d'Epidémiologie Nutritionnelle, INVS/CNAM, \\ Paris, France
}

Submitted 3 November 2004: Accepted 14 June 2005

\begin{abstract}
Background: Iron has been suggested to play a role in the development of cardiovascular disease (CVD) through its pro-oxidant properties. However, epidemiological studies on iron status and the risk of CVD have yielded conflicting results. We therefore carried out a prospective study to evaluate the relationship between iron status and CVD in a middle-aged French population.

Methods: In total, 9917 subjects (3223 men aged 45-60 years and 6694 women aged 35-60 years) included in the SU.VI.MAX (SUpplementation en VItamines et Minéraux AntioXydants) cohort were followed prospectively for 7.5 years. All cases of ischaemic heart disease (IHD) were identified and validated. CVD risk factors, haemoglobin and serum ferritin concentrations were measured at baseline.

Findings: Of men 4.3\%, and of women 37.8\%, presented at baseline a serum ferritin concentration $<30 \mu \mathrm{gl}^{-1}$. During the follow-up, 187 subjects (148 men, 39 women) developed IHD. Serum ferritin was positively associated with total cholesterol, serum triglycerides, systolic and diastolic blood pressure, body mass index and haemoglobin. No linear association was found between serum ferritin and IHD risk in men or in women.

Conclusion: Our data do not support a major role of iron status in the development of IHD in a healthy general population.
\end{abstract}

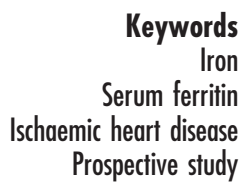

Oxidative stress and free-radical damage to tissues may be involved in the development of cardiovascular disease (CVD). Iron has been suggested to be one of the factors implicated in ischaemic heart damage and lipid peroxidation due to its pro-oxidant properties in generating free radicals ${ }^{1}$. Although there is a strong hypothesis for the mechanism explaining a possible relationship between iron and CVD, the accumulated epidemiological evidence is inconsistent and most studies do not support the role of iron in CVD development ${ }^{2-5}$. Most cross-sectional and case-control studies using serum ferritin as an indicator of iron stores ${ }^{6}$ have not found an association with $\mathrm{CVD}^{5,7-16}$, although some $\mathrm{did}^{17,18}$. However, it has to be taken into account that in these types of studies the disease itself (post-myocardial damage and associated chronic inflammation), its treatment (such as aspirin) and behavioural changes (healthier diet and more physical activity) could influence serum ferritin concentrations and thereby obscure the true relationship. Prospective cohort studies measuring serum ferritin in blood samples collected before the occurrence of CVD avoid these methodological biases. Fourteen prospective studies ${ }^{19-32}$ have been reported, and only a Finnish study ${ }^{19}$ found a statistically significant association between serum ferritin and CVD; after a 3-year follow-up, serum ferritin concentrations $>200 \mu \mathrm{gl} \mathrm{l}^{-1}$ were associated with a 2.2 -fold increase in the incidence of acute myocardial infarction compared with serum ferritin concentrations $<200 \mu \mathrm{gl}^{-1}$. An Italian prospective study examining intermediate endpoints observed an association between serum ferritin and an ultrasound measure of atherosclerosis ${ }^{18}$.

Even though we have an accumulation of studies, the issue of the relationship between iron status and cardiovascular diseases still remains controversial. This may be due to the fact that studies differed in their design (cross-sectional, case-control and prospective studies), the 
chosen endpoints (occurrence of CVD or intermediate endpoints), the population (men, women, healthy or sick people) and the assessment of iron status (serum ferritin, serum transferrin, etc.). Therefore, we carried out a prospective study to evaluate the relationship between iron status, CVD risk factors and the incidence of CVD in a middle-aged population, living in France, where iron supplementation and iron-fortified foods are rarely used ${ }^{33}$.

\section{Materials and methods}

\section{Study population}

Subjects were part of the SU.VI.MAX (SUpplementation en VItamines et Minéraux AntioXydants) study, a doubleblind, placebo-controlled, primary prevention trial evaluating the effect of antioxidant supplementation on chronic diseases. Details concerning study rationale, design, methods and participant characteristics have been reported elsewhere ${ }^{34,35}$. In brief, 12741 French adults (7713 females aged 35-60 years and 5028 males aged 45-60 years) were recruited by a multimedia campaign to be randomly allocated to receive either a combination of antioxidants (120 mg vitamin C, $30 \mathrm{mg}$ vitamin E, $6 \mathrm{mg}$ $\beta$-carotene, $100 \mu \mathrm{g}$ selenium (as selenium-enriched yeast) and $20 \mathrm{mg}$ zinc (as gluconate)) or a matching placebo, in a single daily capsule. Participants did not have known diseases likely to threaten 5-year survival.

The current analysis includes 9917 subjects (3223 men and 6694 women) for whom serum ferritin measurements at baseline were available and who did not have known major inflammatory diseases. The protocol was approved by a medical ethics committee and the national committee for the protection of privacy and civil liberties.

\section{Ascertainment of ischaemic beart disease}

Participants were asked to complete a monthly questionnaire, summarising treatment compliance and health events, via Minitel (a phone-based French terminal), the Internet or mail. If there was no contact with the participant for a long period, or if the participant failed to appear at the yearly visit, an investigation was launched to determine the reasons. Once a CVD event was suspected, all relevant records, including results of diagnostic tests and procedures, were collected from the physicians and hospitals involved or directly from the participant.

All data were reviewed and validated by an expert committee and International Classification of Diseases codes $120-124^{36}$ were used to define ischaemic heart disease (IHD). Causes of death were confirmed by information from relatives or physicians. At the end of the follow-up, vital status of all subjects and causes of death were checked at the national death registry.

\section{Measurement of CVD risk factors and markers of iron status}

Venous blood samples (drawn into mineral-free vacuum tubes; Becton Dickinson, Pont de Chaix, France) were obtained at enrolment from participants who had been fasting for $12 \mathrm{~h}$. Haemoglobin was measured immediately (cyanmethaemoglobin method) and blood was kept at $+4^{\circ} \mathrm{C}$ in the dark until centrifugation and preparation of aliquots. Aliquots of serum were frozen in polypropylene tubes and shipped to the coordination centre in Paris for storage.

Serum ferritin concentration was used as a marker of body iron stores and measured using automatic nephelometry (BNII nephelometer; Dade Behring, Paris La Défence, France). The laboratory quality assurance included analysis of serum from standard pools with each run and international standards.

Total cholesterol and serum triglycerides were measured using an enzymatic method (Technicon Dax 24; Bayer Diagnostic, Puteaux, France).

Blood pressure was measured at the first clinical examination (1995-1996), using a standardised procedure with a standard mercury sphygmomanometer. Blood pressure was measured once at each arm in subjects who had been lying down for $10 \mathrm{~min}$, and the mean of these two measurements was used for analyses. Body mass index (BMI) was also measured at 1 year and was calculated from measured weight and height.

\section{Statistical analyses}

Follow-up time for each subject was calculated from the date of randomisation until the date of IHD diagnosis, date of death or 1 September 2002.

The difference in CVD risk factors, haemoglobin and serum ferritin between cases and non-cases was evaluated using a $t$-test. The association between serum ferritin and CVD risk factors was evaluated by calculating the Spearman correlation coefficient. Because of skewed distributions, serum levels of ferritin were log-transformed for analysis and geometric means are presented. Cox proportional-hazards models were used to calculate the maximum likelihood estimates of the relative risk and its 95\% confidence interval to evaluate the relationship between serum ferritin and IHD. For these analyses, serum ferritin concentrations were separated according to the following definition based on data regarding ferritin and iron absorption ${ }^{12}$ : depleted and low status, $<30 \mu \mathrm{gl}^{-1}$ (taken as the referent group); nonreplete and borderline normal status, 31-70 $\mu \mathrm{g}^{-1}$; replete and adequate status, $71-160 \mu \mathrm{gl}^{-1}$; and replete and elevated status, $>160 \mu \mathrm{gl}{ }^{-1}$. In all analyses, the relative risks were adjusted for possible confounding factors (age, smoking, BMI, total cholesterol, serum triglycerides, supplementation group and menopausal status).

Statistical analyses were performed using SAS software version 8.2 (SAS institute, Inc., Cary, NC, USA) and were performed separately for men and women. 
Table 1 Risk factors for cardiovascular disease and markers of iron status in the study population

\begin{tabular}{lcc}
\hline & Men & Women \\
\hline$n$ & 3223 & 6694 \\
Age (years) & $51.8(4.7)$ & $47.0(6.6)$ \\
Smoking (\%) & & \\
$\quad$ Non-smokers & 34.0 & 55.0 \\
$\quad$ Former smokers & 51.7 & 29.2 \\
$\quad$ Current smokers & 14.3 & 15.8 \\
Body mass index $\left(\mathrm{kg} \mathrm{m}^{-2}\right)$ & $25.6(3.2)$ & $23.4(4.0)$ \\
Blood pressure $\left(\mathrm{mmHg}^{2}\right.$ & & \\
$\quad$ Systolic & $129.1(13.9)$ & $119.7(13.6)$ \\
$\quad$ Diastolic & $83.4(8.4)$ & $76.9(8.5)$ \\
Total cholesterol $\left(\mathrm{mmoll}^{-1}\right)$ & $6.2(1.0)$ & $5.9(1.0)$ \\
Serum triglycerides $\left(\mathrm{mmol}^{-1}\right)$ & $1.41(1.1)$ & $0.90(0.5)$ \\
Haemoglobin $\left(\mathrm{gl}^{-1}\right)$ & $149.7(10.3)$ & $135.0(10.5)$ \\
Serum ferritin $\left(\mu \mathrm{gl}^{-1}\right)$ & $195.1(154.6)$ & $54.9(54.8)$ \\
& $144.3^{*}$ & $36.3^{*}$ \\
\hline
\end{tabular}

Values are means (standard deviation) unless indicated otherwise. * Geometric mean.

\section{Results}

Baseline characteristics of the population are presented by sex in Table 1. Men were older but the percentage of current smokers was not different between sexes. As expected, mean BMI, total cholesterol and serum triglycerides, systolic and diastolic blood pressure, haemoglobin and serum ferritin concentrations were higher in men than in women.

Of men $4.3 \%$, and of women $37.8 \%$, presented at baseline a serum ferritin concentration $<30 \mu \mathrm{gl} \mathrm{l}^{-1}$; and serum ferritin level in the range $30-70 \mu \mathrm{g}{ }^{-1}$ was found in $11.2 \%$ and $26.3 \%$, respectively. Serum ferritin was positively correlated with total cholesterol $(r=0.15$; $P<0.001)$, serum triglycerides $(r=0.32 ; P<0.001)$, systolic blood pressure $(r=0.26 ; P<0.001)$, diastolic blood pressure $(r=0.24 ; P<0.001)$, BMI $(r=0.27$; $P<0.001)$ and haemoglobin $(r=0.41 ; P<0.001)$.
During the median follow-up time of 7.54 years, 187 subjects (148 men, 39 women) developed IHD. In both sexes, subjects who subsequently developed IHD were older, more often current smokers, and had higher BMI, systolic and diastolic blood pressure, and higher concentrations of total cholesterol and serum triglycerides (Table 2). Furthermore, they had a higher mean serum ferritin concentration, although this difference was not statistically significant at the $5 \%$ level in women. No statistically significant differences were observed for haemoglobin.

No relationship was found between serum ferritin and IHD risk in men and in women before and after adjustment (Table 3).

\section{Discussion}

In this prospective study performed in a French population, the risk of IHD was not related to serum ferritin. In 1981, Sullivan ${ }^{37}$ proposed for the first time that body iron stores are positively related to coronary heart disease (CHD) risk. The theory was that production of free radicals that subsequently modify low-density lipoprotein cholesterol was important in the development of atherosclerosis and that iron stimulates the catalysis of oxidation reactions that produce free radicals ${ }^{2,3}$. In 1992 a Finnish study confirmed this hypothesis, showing a positive relationship between serum ferritin and risk of acute myocardial infarction in men $^{19}$, after which interest in this theory grew. However, most other studies do not support the theory ${ }^{2-5}$ and a recent meta-analysis ${ }^{38}$ of prospective studies comparing subjects with serum ferritin concentration $>200 \mu \mathrm{gl}^{-1}$ versus those having serum ferritin $<200 \mu \mathrm{gl}^{-1}$ reported a combined risk ratio for CHD of 1.03 (95\% confidence interval: 0.83-1.29). In addition to the use of serum ferritin as a marker of iron

Table 2 Risk factors for cardiovascular disease and markers of iron status according to sex and ischaemic heart disease (IHD) status

\begin{tabular}{|c|c|c|c|c|c|c|}
\hline & \multicolumn{3}{|c|}{ Women } & \multicolumn{3}{|c|}{ Men } \\
\hline & IHD & No IHD & $P$-value & IHD & No IHD & $P$-value \\
\hline$n$ & 39 & 6655 & & 148 & 3075 & \\
\hline Age (years) & $51.0(6.9)$ & $46.9(6.5)$ & 0.0001 & $54.0(4.8)$ & $51.7(4.7)$ & $<0.0001$ \\
\hline \multicolumn{7}{|l|}{ Smoking (\%) } \\
\hline Non-smokers & 55.3 & 55.0 & 0.59 & 28.1 & 34.3 & 0.0002 \\
\hline Former smokers & 23.7 & 29.2 & & 45.9 & 52.0 & \\
\hline Current smokers & 21.1 & 15.8 & & 26.0 & 13.7 & \\
\hline Body mass index $\left(\mathrm{kg} \mathrm{m}^{-2}\right)$ & $25.0(5.0)$ & $23.4(4.0)$ & 0.02 & $26.5(3.4)$ & $25.50(3.2)$ & 0.0007 \\
\hline \multicolumn{7}{|l|}{ Blood pressure (mmHg) } \\
\hline Systolic & $128.2(16.9)$ & $119.6(13.5)$ & 0.0004 & $135.3(15.9)$ & $128.8(13.8)$ & $<0.0001$ \\
\hline Diastolic & $82.1(10.3)$ & $76.9(8.5)$ & 0.0007 & $86.2(8.8)$ & $83.3(8.4)$ & 0.0003 \\
\hline Total cholesterol $\left(\mathrm{mmoll}^{-1}\right)$ & $6.5(1.1)$ & $5.9(1.0)$ & $<0.0001$ & $6.6(1.0)$ & $6.2(1.0)$ & $<0.0001$ \\
\hline Serum triglycerides $\left(\mathrm{mmoll}^{-1}\right)$ & $1.1(0.5)$ & $0.9(0.5)$ & 0.03 & $1.8(1.5)$ & $1.4(1.0)$ & $<0.0001$ \\
\hline Haemoglobin $\left(\mathrm{gl}^{-1}\right)$ & $137.1(10.3)$ & $135.0(10.5)$ & 0.24 & $151.0(11.5)$ & $149.7(10.2)$ & 0.17 \\
\hline Serum ferritin $\left(\mu \mathrm{gl}^{-1}\right)$ & $47.8^{*}$ & $36.3^{*}$ & 0.08 & $165^{\star}$ & $143^{*}$ & 0.05 \\
\hline
\end{tabular}

Values are means (standard deviation) unless indicated otherwise.

* Geometric mean. 
Table 3 Relative risk for ischemic heart disease (IHD) according to serum ferritin concentration

\begin{tabular}{|c|c|c|c|c|c|c|}
\hline & \multicolumn{3}{|c|}{ Men } & \multicolumn{3}{|c|}{ Women } \\
\hline & \multirow{2}{*}{$\begin{array}{l}\text { No. IHD cases/total } \\
\text { no. of subjects }\end{array}$} & \multicolumn{2}{|c|}{$\mathrm{RR}(95 \% \mathrm{Cl})$} & \multirow{2}{*}{$\begin{array}{l}\text { No. IHD cases/total } \\
\text { no. of subjects }\end{array}$} & \multicolumn{2}{|c|}{$\mathrm{RR}(95 \% \mathrm{Cl})$} \\
\hline & & Crude & Adjusted* & & Crude & Adjusted $†$ \\
\hline \multicolumn{7}{|l|}{ Serum ferritin } \\
\hline$<30 \mu \mathrm{gl}^{-1}$ & $11 / 318$ & 1.00 & 1.00 & $19 / 3977$ & 1.00 & 1.00 \\
\hline $30-70 \mu \mathrm{gl}^{-1}$ & $19 / 609$ & $0.77(0.29-2.05)$ & $0.66(0.21-1.96)$ & $12 / 1832$ & $0.88(0.41-1.88)$ & $0.70(0.28-1.76)$ \\
\hline $70-160 \mu \mathrm{gl}^{-1}$ & $55 / 1125$ & $0.96(0.41-2.24)$ & $0.85(0.33-2.18)$ & 4/727 & $1.14(0.49-2.64)$ & $0.95(0.35-2.56)$ \\
\hline$>160 \mu \mathrm{gl}^{-1}$ & $63 / 1171$ & $1.45(0.64-3.33)$ & $1.31(0.52-3.27)$ & $4 / 158$ & $2.42(0.80-7.38)$ & $2.18(0.64-7.43)$ \\
\hline
\end{tabular}

$\mathrm{RR}$ - relative risk; $\mathrm{Cl}$ - confidence interval.

${ }^{*}$ Adjusted for age, smoking, body mass index, total cholesterol, serum triglycerides and group of supplementation.

† Adjusted for age, smoking, body mass index, total cholesterol, serum triglycerides, menopausal status and group of supplementation.

status, the comparison of blood donors with non-donors appears to provide useful information on the irondepletion hypothesis because of the marked contrast in body iron stores of regular donors compared with nondonors $^{39}$. However, of three published studies on blood donation $^{39-41}$, two did not find any difference between the groups and one found a significant inverse relationship with $\mathrm{CHD}^{41}$. Our results are thus consistent with most of these studies that have failed to support the hypothesis that body iron stores are associated with risk of CHD.

On the other hand, in our study serum ferritin was related to established coronary risk factors, as has been shown in other studies ${ }^{19,42-44}$. It is possible that ferritin may play a role through other risk factors such as cholesterol, triglycerides, obesity or blood pressure, but no association between serum ferritin and IHD was seen even before adjustment for CVD risk factors.

In conclusion, our results taken together with the accumulated evidence from previous prospective studies do not support a major role of iron in of the development of IHD.

\section{Acknowledgements}

Funding/support: The SU.VI.M.AX project received support from public and private sectors. Special acknowledgements are addressed to Fruit d'Or Recherche, Lipton, Cereal, Candia, Kellogg's, CERIN, LU/Danone, Sodexho, L'Oréal, Estée Lauder, Peugeot, Jet Service, RP Scherer, France Telecom, Becton Dickinson, Fould Springer, Boehringer Diagnostic, Seppic Givaudan Lavirotte, Le Grand Canal, Air Liquide, Carboxyque, Klocke, Trophy Radio, Jouan and Perkin Elmer.

Conflict of interest: None declared.

\section{References}

1 Halliwell B, Gutteridge JMC. Oxygen free radicals and iron in relation to biology and medicine: some problems and concepts. Archives of Biochemistry and Biophysics 1986; 246: $501-14$
2 Sempos CT, Looker AC, Gillum RF. Iron and heart disease: the epidemiologic data. Nutrition Reviews 1996; 54: 73-84.

3 Meyers DG. The iron hypothesis: does iron cause atherosclerosis? Clinical Cardiology 1996; 19: 925-9.

4 Sempos CT. Do body iron stores increase the risk of developing coronary heart disease? American Journal of Clinical Nutrition 2002; 76: 501-3.

5 Ma J, Stampfer MJ. Body iron stores and coronary heart disease. Clinical Chemistry 2002; 48: 601-3.

6 Cook JD, Lipschitz DA, Miles LE, Finch CA. Serum ferritin as a measure of iron stores in normal subjects. American Journal of Clinical Nutrition 1974; 27: 681-7.

7 Bozzini C, Girelli D, Yinazzi E, Olivieri O, Stranieri C, Bassi A, et al. Biochemical and genetic markers of iron status and the risk of coronary artery disease: an angiography-based study. Clinical Chemistry 2002; 48: 622-8.

8 Sempos CT, Looker AC, Gillum RE, McGee DL, Vuong CV, Johnson CL. Serum ferritin and death from all causes and cardiovascular disease: the NHANES II Mortality Study. National Health and Nutrition Examination Study. Annals of Epidemiology 2000; 10: 441-8.

9 Aronow WS. Serum ferritin is not a risk factor for coronary artery disease in men and women aged $>62$ years. American Journal of Cardiology 1993; 72: 347-8.

10 Solymoss BC, Marcil M, Gilfix BM, Gelinas F, Poitras AM, Campeau L. The place of ferritin among risk factors associated with coronary artery disease. Coronary Artery Disease 1994; 5: 231-5.

11 Rauramaa R, Väisänen S, Mercuri M, Rankinen T, Penttila I, Bond MG. Association of risk factors and body iron status to carotid atherosclerosis in middle-aged Eastern Finnish men. European Heart Journal 1994; 15: 1020-7.

12 Duthie GG, Beattie JAG, Arthur JR, Franklin M, Morrice PC, James WPT. Blood antioxidants and indices of lipid peroxidation in subjects with stable angina. Nutrition 1994; 10: $313-31$

13 Rengström J, Tonrvall P, Kallner A, Nilsson J, Hamsten A. Stored iron levels and myocardial infarction at a young age. Atherosclerosis 1994; 106: 123-5.

14 Moore M, Folsom AR, Barnes RW, Eckfeldt JH. No association between serum ferritin and asymptomatic carotid atherosclerosis. The Atherosclerosis Risk in Communities (ARIC) Study. American Journal of Epidemiology 1995; 141: 719-23.

15 van der Schouw YT, Verbeek A, Ruijs J. ROC curves for the initial assessment of new diagnostic tests. Family Practice 1992; 9: 506-11.

16 Eichner JE, Qi H, Moore WE, Schechter E. Iron measures in coronary angiography patients. Atherosclerosis 1998; 136: $241-5$.

17 Wolff B, Volzke H, Ludemann J, Robinson D, Vogelgesang D, Staudt A, et al. Association between high serum ferritin levels 
and carotid atherosclerosis in the study of health in Pomerania (SHIP). Stroke 2004; 35: 453-7.

18 Kiechl S, Aichner F, Gerstenbrand F, Egger G, Mair A, Rungger $\mathrm{G}$, et al. Body iron stores and the risk of carotid atherosclerosis: prospective results from the Bruneck study. Circulation 1997; 96: 3300-7.

19 Salonen JT, Nyyssonen K, Korpela H, Tuomilehto J, Seppanen R, Salonen R. High stored iron levels are associated with excess risk of myocardial infarction in eastern Finnish men. Circulation 1992; 86: 803-11.

20 Salonen JT, Nyyssonen K, Salonen R. Body iron stores and the risk of coronary heart disease [letter]. New England Journal of Medicine 1994; 331: 1159.

21 Stampfer MJ, Grodstein F, Rosenberg I, Willett WC, Hennekens $\mathrm{CH}$. A prospective study of plasma ferritin and risk of myocardial infarction in US physicians [abstract]. Circulation 1993; 87: 10 .

22 Manttari M, Manninen V, Huttunen JK, Palosuo T, Ehnholm $\mathrm{C}$, Heinonen OP, et al. Serum ferritin and ceruloplasmin as coronary risk factors. European Heart Journal 1994; 15 1599-603.

23 Magnusson MK, Sigfusson N, Sigvaldason H, Johannesson M, Magnusson S, Thorgeirsson G. Low iron-binding capacity as a risk factor for myocardial infarction. Circulation 1994; 89: $102-8$.

24 Frey GH, Krider DW. Serum ferritin and myocardial infarct. West Virginia Medical Journal 1994; 90: 13-5.

25 Baer DM, Tekawa IS, Hurley LB. Iron stores are not associated with acute myocardial infarction. Circulation 1994; 89: 2915-8.

26 Sempos CT, Looker AC, Gillum RF, Makuc DM. Body iron stores and the risk of coronary heart disease. New England Journal of Medicine 1994; 330: 1119-24.

27 Liao Y, Cooper RS, McGee DL. Iron status and coronary heart disease: negative findings from the NHANES I epidemiologic follow-up study. American Journal of Epidemiology 1994; 139: $704-12$.

28 Reunanen A, Takkunen H, Knekt P, Seppanen R, Aromaa A Body iron stores, dietary iron intake and coronary heart disease mortality. Journal of Internal Medicine 1995; 238 223-30.

29 van Asperen IA, Feskens EJM, Bowles CH, Kromhout D. Body iron stores and mortality due to cancer and ischaemic heart disease: a 17-year follow-up study of elderly men and women. International Journal of Epidemiology 1995; 24: $665-70$.

30 Morrison HI, Semenciw RM, Mao Y, Wigle DT. Serum iron and risk of fatal acute myocardial infarction. Epidemiology 1994; 5: 243-6.

31 Ascherio A, Willett WC, Rimm EB, Giovannucci EL, Stampfer MJ. Dietary iron intake and risk of coronary disease among men. Circulation 1994; 89: 969-74.
32 Knuiman MW, Divitini ML, Olynyk JK, Cullen DJ, Bartholomew HC. Serum ferritin and cardiovascular disease: a 17-year follow-up study in Busselton, Western Australia. American Journal of Epidemiology 2003; 158: 144-9.

33 Galan P, Yoon H-C, Preziosi P, Viteri F, Valeix P, Fieux B, et al. Determining factors in the iron status of adult women in the SU.VI.MAX study. European Journal of Clinical Nutrition 1998; 52: 383-8.

34 Hercberg S, Preziosi P, Briançon S, Galan P, Paul-Dauphin A, Malvy D, et al. A primary prevention trial of nutritional doses of antioxidant vitamins and minerals on cardiovascular diseases and cancers in general population: The SU.VI.MAX Study. Design, methods and participant characteristics. Controlled Clinical Trials 1998; 19: 336-51.

35 Hercberg S, Galan P, Preziosi P, Bertrais S, Mennen L, Malvy D, et al. The SUVI MAX study: a randomised, placebocontrolled trial of the health effects of antioxidant vitamins and minerals. Archives of Internal Medicine 2004; 164: 1-8.

36 World Health Organization (WHO). International Statistical Classification of Diseases and Related Health Problems, 10th version. Geneva: WHO, 1992.

37 Sullivan JL. Iron and the sex difference in heart disease risk. Lancet 1981; 1: 1293-4.

38 Danesh J, Appleby P. Coronary heart disease and iron status. Meta-analyses of prospective studies. Circulation 1999; 99 $852-4$.

39 Ascherio A, Rimm EB, Giovannucci E, Willett WC, Stampfer MJ. Blood donations and risk of coronary heart disease in men. Circulation 2001; 103: 52-7.

40 Meyers DG, Strickland D, Maloley PA, Seburg JK, Wilson JE, McManus BF. Possible association of a reduction in cardiovascular events with blood donation. Heart 1997; 78 188-93.

41 Salonen JT, Tuomainen TP, Salonen R, Lakka TA, Nyyssonen K. Donation of blood is associated with reduced risk of myocardial infarction. The Kuopio Ischaemic Heart Disease Risk Factor Study. American Journal of Epidemiology 1998; 148: 445-51

42 Williams MJA, Poulton R, Williams S. Relationship of serum ferritin with cardiovascular risk factors and inflammation in young men and women. Atherosclerosis 2002; 165: 179-84.

43 Oshaug A, Bugge $\mathrm{KH}$, Bjonnes $\mathrm{CH}$, Borch-Iohnsen B, Neslein IL. Associations between serum ferritin and cardiovascular risk factors in healthy young men: a cross sectional study. European Journal of Clinical Nutrition 1995; 49: 430-8.

44 Halle M, Konig D, Berg A, Keul J, Baumstark MW. Relationship of serum ferritin concentrations with metabolic cardiovascular risk factors in men without evidence for coronary artery disease. Atherosclerosis 1997; 128: 235-40. 